\title{
$(266)$
}

XVII. Observations on the Durion, Durio zibethinus of Linnaus. By Mr. Charles König, F.L.S.

Read December 6, 1803.

$T_{\text {He vegetable genus which constitutes the object of this Paper, }}$ and of which I had an opportunity of examining the flowers, fruit, and a small branch, through the kindness of the Rt. Hon. Sir Joseph Banks, to whom they were sent from Amboyna by Mr. Christopher Smith, F. L.S. ranks high in the number of those which have a just claim to re-examination; for the characters hitherto attributed to it are vague and erroneous. Linnæus, who first introduced the Durio as a genus in the thirteenth edition of his Systema Plantarum, had not seen any part of the plant; he therefore took the generic character from Rumpf's Herbarium Amboinense : a work very useful, upon the whole, for ascertaining the general habit and the history of the vegetables of which it treats, but scarcely in any instance sufficient, either by its delineations or descriptions, to convey an adequate idea of the parts of a plant, or to be depended on for establishing generic characters. The fact is, that Rumpf's figure of the flowers of the Durion does not even express their habit; nor can any knowledge be derived from his description, which, as may be naturally expected, bears testimony of the period in which it was composed. But the Latin translation which is added to this work misleads still more than the Dutch original. It is, I suppose, from consulting this translation that Linnæus describes the ovarium of the Durion as stipitate, which is contrary to what $I$ have observed ;

nor, 
nor, indeed, is it described as such in the original*. It was this mistaken notion which, probably, induced Jussieu (whose very errors respecting the natural arrangement of plants are often indicative of much discernment) to class the plant in question with the Capparides. That it does not, however, belong to this order, but must be transferred to that of the Malvacea; in the proximity of Bombax, Adansonia, or Carolinea, will, perhaps, appear from the following description:

\section{DURIO zIBETHINUS.}

$C_{\Lambda \text { LY }}$ duplex: uterque inferus, monophyllus, subcoriaceus, intus glaber, extus nitidis squamis argenteus: squamæ minutissimæ, patellatæ, radiatæ, margine erosæ, pellucidæ, centro puncto nigro nutatee.

Exterior latus, fundo pro excipiendo interiore excavatus, bilobus: lobi lineas novem ad pollicem longi, concavi, obtusi, patentes.

Interior pollicaris, urceolatus, medio ventricosus, obsolete quinquesulcatus, basi attenuatus, fundo maculis quinque prominulis (nectariis?) notatus, ore dentatus : dentes quinque, recti, acuti.

Conolta: Petala quinque, fundo calycis inserta, bipollicaria, squalide alba, unguiculata. Laminee ovato-lanceolatæ, patenti-reflexæ, integerrimæ, sensim abeuntes in Ungues breviores, crassiusculos, longitudinaliter sulcatos.

* The following is a translation of Rumpf's own words :- "s Exactly in the middle (of the flower) there is a long style, with a yellow head (stigma), situate (the style, but not the stigma) on an oblong, granulous knob (germen), which becomes the fruit ;" which the Latin translator has given thus :-_" In horum centro longus continetur stylus, qui luteum gerit capitulum, avoD oblongo insidet granuloso pistillo, quod abit in fructum." 
Sramina : Filamenta plurima (25-45), filiformia, rubra, erecta, petalis paululum longiora (ante efflorescentiam multum breviora), subdichotoma, connata infra medium in phalanges quinque petalis oppositas, fundoque calycis insertas. Anther $\&$ rotundatæ, mesenteriformes: lamellæ curvatæ, subpedicellatæ, rubræ, marginibus albis.

Pisticlum: Ovarium superum, ovato-oblongum, obsolete pentagonum, primo squamulis argenteis postea granulis undique obsitum, neutiquam stipitatum. Stylus simplex, longitudine. et colore filamentorum, teres, filiformis, basi crassior, superne subintortus. Stigma capitatum, quinquesulcatum, flavens.

Fructus : Pomum maximum, ovato-rotundatum s. rotundum, in vertice umbonatum, quinqueloculare, corticatum : Cortex crassus, duriusculus, undique obsitus tuberculis 5--hexaëdris, pyramidatis, suberosis, innocue mucronatis, fibrosis, flavo-virescentibus, medio fructus pollicaribus, versus extremitates minoribus, ad pedunculum crassum in squamas conicas abeuntibus. Caro solida, fibris rubentibus intertexta. Loculamenta quinque, longitudine fere fructus, extrorsum dehiscentia, undique lævigata excepto latcre pistillari* cum quo semina, mediantibus arillis, arcte connata sunt.

Semina in singulo loculamento $2-5$, nitida, spadiceo-lutea, ovato-oblonga, hinc convexa inde planiuscula, ab altero latere versus basin derasa, arillata.

* An excellent carpologist, Dr. Corrêa de Serra (Linn. Trans. vol. 5..p. 222), calls chorda pistillaris that aggregation of longitudinal fibres and vessels, which in most fleshy fruits may be traced from their insertion in the receptacle up to the stigma, and to which the seeds are affixed. This bundle is less obwious in the fruit of the Durion, the whole of its flesh being interwoven with fibres; but still it exists: whence I apply the term of latus pistillare to the side of the loculaments next to the'centre of the fruit. 
Arilli horizontaliter aut oblique incumbentes loculamento conformes, irregulares: medii majores, supremus infimusque attenuati; omnes sublobati, crassi, carnoso-mucosi, tenerrimi, albi, ad mutuum contactum oblique truncati, latere interno cum centro fructus pistillari arctissime connati, ceterum liberi, membrana tenuissima pellucida separatim obducti.

Testa ex duabus paginis conferruminatis conflata: pagina exteriore solida, duriore; interiore suberosa, subcellulosa: cellulis fluidum fuscum coercentibus.

Perisperma nullum.

Embryo dicotyledoneus, testæ cavitatem explens, rectus.

Cotyledones amygdalino-carnosæ, ovato-oblongæ, parte superiore-eonfer incisæ.

Radicula intra extremitates cotyledonum liberas latens, inverse subpyramidalis, obsolete tetragona.

Obs. 1. Though this description does not in every point exactly answer the characteristic of the order of the Malvacea, as it now stands; yet it cannot be denied that many characters which I have pointed out, such as the double calyx, the connected stamens, the conglomerated anthers (which we observe exactly similar in several other Malvaceous plants, for instance, in Bombax pentandrum), nay eren the fruit itself, so anomalous at first sight, strongly indicate at least the neighbourhood in which the Durion is to be placed in natural arrangement. The place assigned to it by Jussieu is warranted by the idea which this naturalist entertained of the germen being stipitate, and by the scales on the under surface of its leaves, which very much resemble those that cover the surface of the leaves of several Capparides; but the first character, as I have shown, is erroneous, and the other is of less importance, and only indicative of the affinity subsisting between both families.

Obs. 2. 
Obs. 2. I have described the fruit as containing five loculaments outwardly dehiscent at the period of maturity; and this is all I ventured to say, from what I was able to observe in the specimens of the fruit preserved in spirits. In these I could distinguish, at equal distances, the lines where the fruit was to gape, and which divided each of the loculaments into two equal parts. This naturally suggested to me the idea of a Capsula baccata, with valves, two of which conjoinedly form each of the loculaments (valvula medio septiferce); a conformation proper to the fruit of a great number of Malvacea. Finding, however, that the septa which separate the loculaments were too intimately connected with the central or pistillar part of the fruit, and without any appearance of division, it seemed more probable to me that no separation took place in the centre; and hence I made use of the more ambiguous term Pomum, which also, according to the sense in which it is taken by our great master in carpology, the late Dr. Gærtner, holds in many cases a midway between capsule and berry. From Rumpf's account, which corresponds with my supposition, we learn, that in order to try whether a Durion-fruit be fit for eating, the amateurs usually tread upon it with the foot : if ripe, it gives way in five places by as marry natural fissures, which exhibit five loculaments.

Obs. 3. The fleshy delicate substance which fills the loculaments of this fruit, and contains, within separate lobes, the seeds, I hare denoted in the description by the term of aril; which may, perhaps, appear objectionable on account of the unusual form and size of these parts: but they accord pretty well with the notion which we have of an aril; for each of these lobes is an accessory integument of a seed, with which it is grown together only at its umbilical part. Our physiological insight into the nature and economy of many of the parts surrounding the seeds is still too 
limited to keep them all distinct by adequate definitions; and this is also the case with what is termed the aril of the seed. But sometimes this term is applied to parts which obviously have no claim to it: thus, for instance, what Gxortner gives as an instance of Arilliss baccatus in the Litchi (Scytalia chinensis $G$.) is nothing else but the pulp of this delicious fruit, which the same author improperly calls a Bacca exsucca: this pulp, when the fruit becomes dried, separates from the hard outward skin in all points, except at the base, and, concentrating round the kernel, exhibits the shape in which it is represented in the incomparable work of Gærtncr.

The only-species of the gen Durio is that highest of all fruittrees, known by the names of Durion and Dureyn. It is not found in the western parts of India, but begins in Malacca, and is continucd on through Java, Madura, Borneo, the Celebes, and all the Moluccas. Rumpf and other ocular witnesses describe its thin and spreading head as supported by an angular and as it were winged stem, covered with an even and greyish yellow bark, which distinguishes this tree among all others. The leaves are alternate, from four to five inches in length, oblong, acuminate, cntire, rather plaited at the base, above smooth and of a decp green hue; below covered with minute rust-coloured scales, and maked by a strongly elevated longitudinal rib, emitting distinct and arcuate lateral branches. Their stalks are an inch long, fleshy, swoln, and likewise covered with minute scales. No stipules were observable in those small branches which fell under my examination, but it appeared as if there were some traces of their former existence. The inflorescence of the Durion is such as we see in all trees bearing heary fruit, as in the Jack, Bread- 
fruit tree, \&c.: the flowers are situate on the thicker branches, in bunches supported by a common stalk; the partial stalks are 2-3 inches long, roundish, covered like the calyx with minute scales, and inserted in the common peduncle by means of a joint.

There are several varieties of the Durion specified by Rumpf, only differing from each other by the shape and size of the fruit. The Durion is represented by those who were in the habit of eating it, as the most delicious of all the fruits of India. The eatable part of it is that aril-like substance which contains the kernels, and which most resembles cream or the blanc-manger of our tables; but a considerable drawback from the extreme gratification it procures to the palate of the epicurean is its intolerable stench: even the rinds emit such offensive effuvia, that at Amboyna, as Rumpf and Valentin state, it is forbidden by the law' to throw them out near any public path. Some compare this smell to that of putrid animal substances, others to that of rotten onions; but al,agree that, if the first repugnance is once overame, no fruit is more enticing than the Durion. These qualities arevo very well known, that $I$ was surprised to find it mentioned in th Histoire deVoyages, and copied from thence by Lamarck in his Encyclopedie; that the fruit of the Durion diffuses an excellent odour, bu that its taste is rather unpleasant, it being that of fried onions *. There are besides other errors in this description; for instance, that the fruit opens in four places, and so forth.

\footnotetext{
* "Il n'est bon à manger que loreque l'écorce s'ouvre par le haut; le dedans, qui est alors parfaitement mûr, donne une odeur excellente.-L'habitude y fait trouver un goût exquis; mais ceux qui en mangent rarement ou pour la premiere fois, lui trouvent d'abord un goat d'oignon roti, qui ne leur paroît pas fort agréab́le."
} 


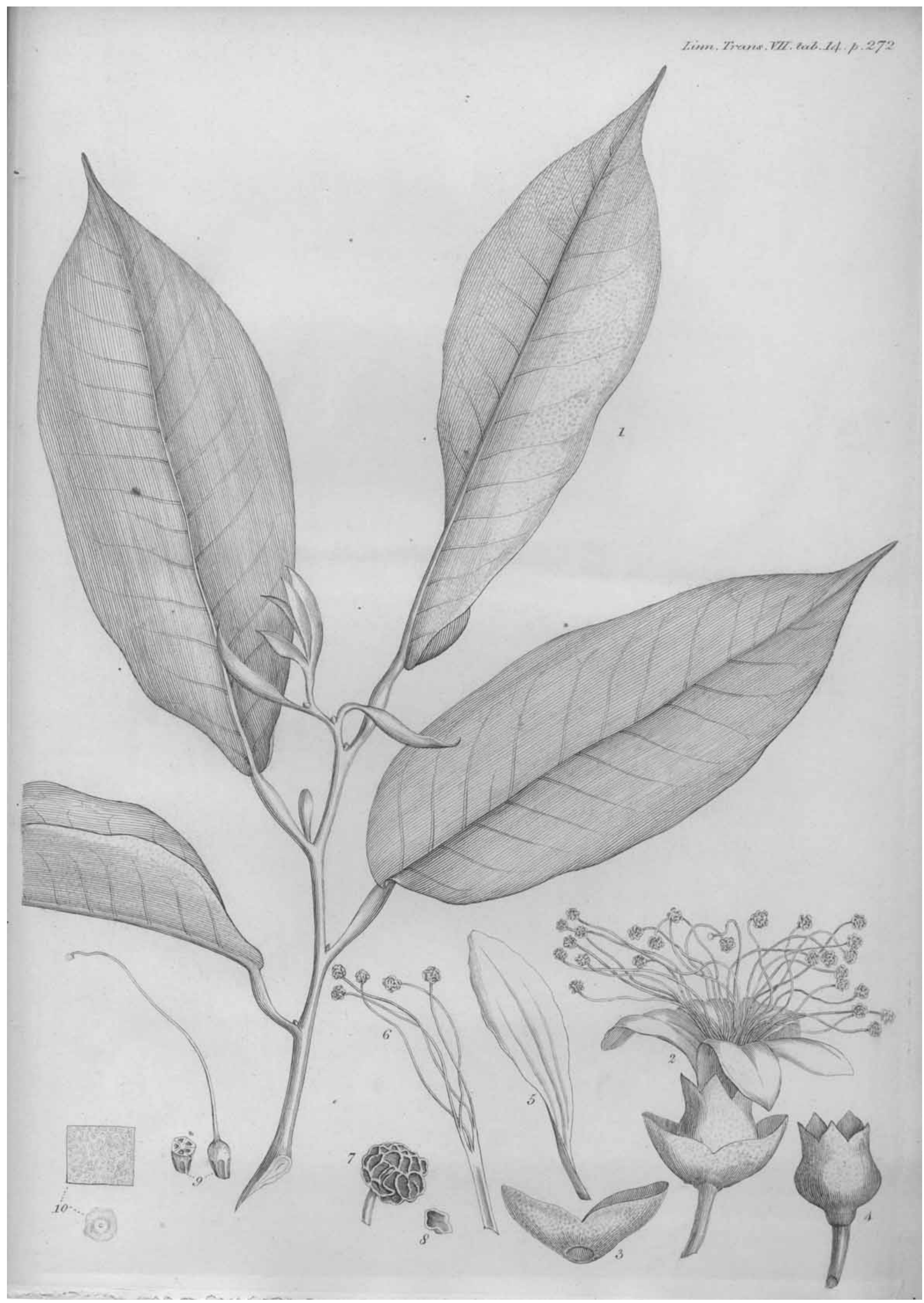




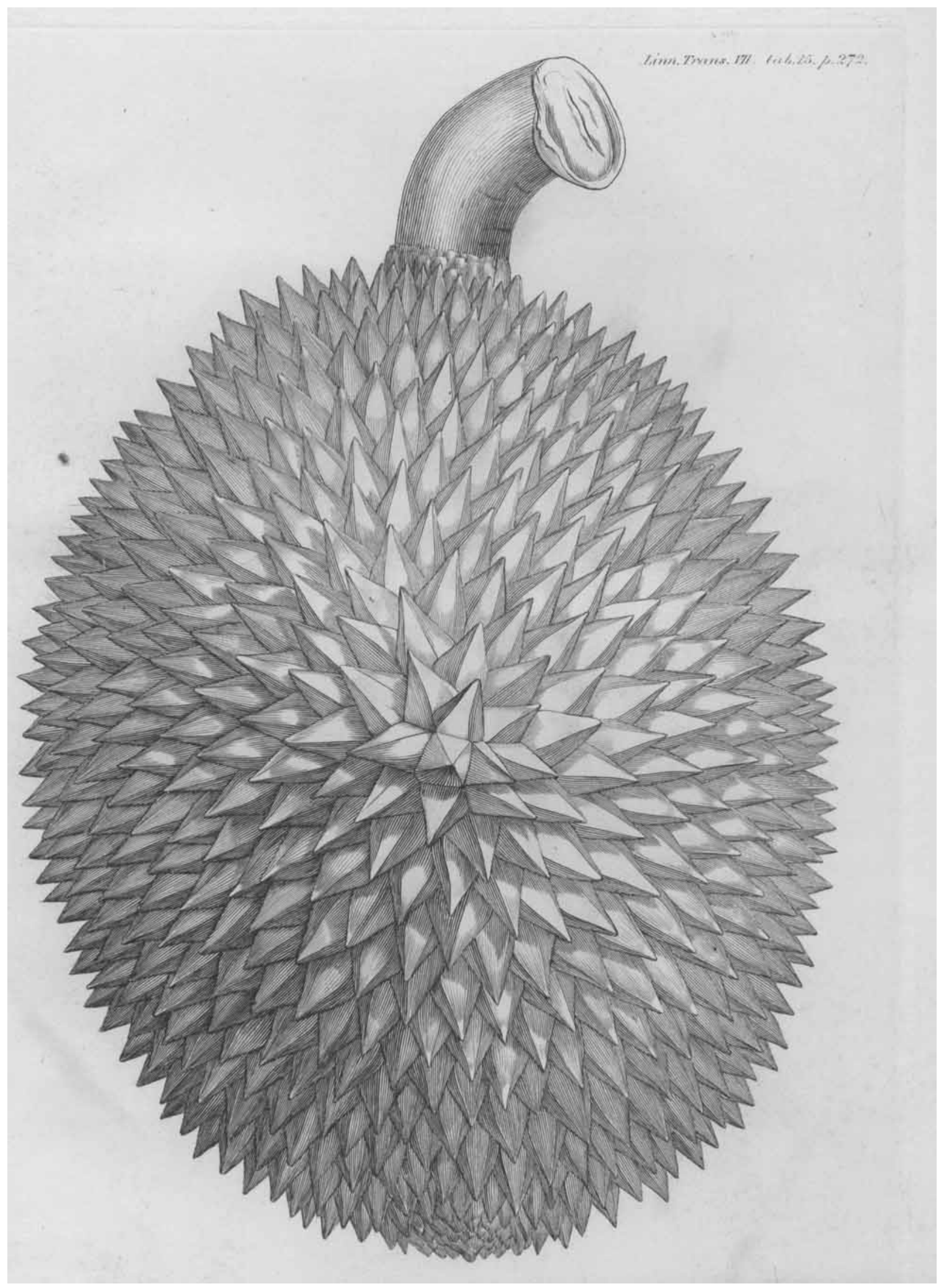




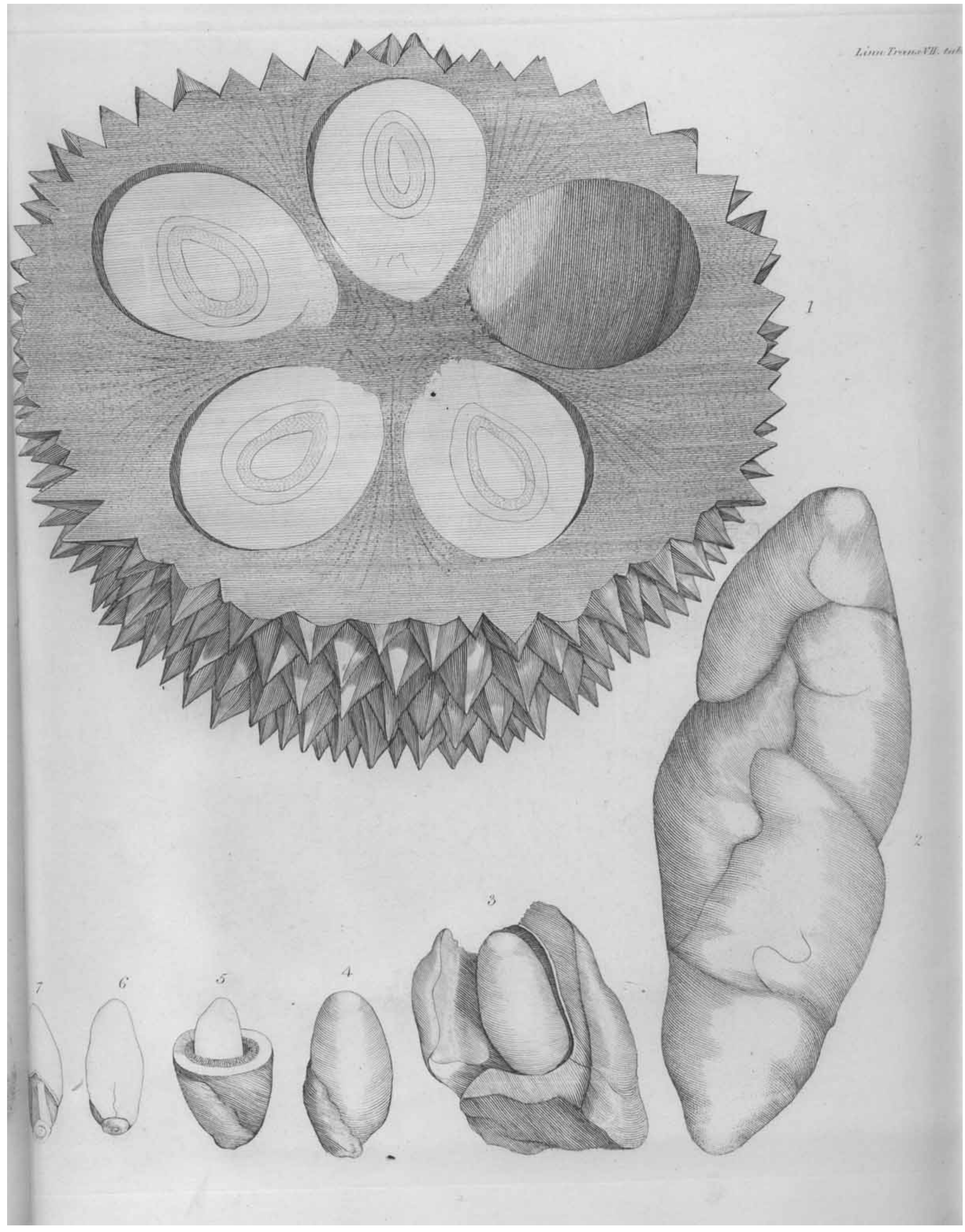


Durio zibethinus of Linncus.

\section{EXPLANATION OF THE ANNEXED PLATES.}

Tab. XIV. Fig. 1. A small branch of Durio zibethinus.

2. A complete flower of the same.

3 . The outer calyx, separately.

4. The inner calyx.

5. A petal.

6. A phalanx of stamens.

7. An anther, magnified.

3. A lamella of the same.

9. The ovarium and style.

10. A piece of the scaly surface of the calyx and

Tab. XV. a scale magnified.

Tab. XVI. Fig. 1. A transversal section of the same.

2. The mass of arils or fleshy lobes enveloping the kernels, taken out of the loculament.

3. A single to same, opened to show the situation of the seed.

4. The seed, detached.

5. Transversal section of the same.

6. The embryo, entire.

7. The same, with a part of the conferruminated cotyledons cut off, to show the situation of the radicle. 